\title{
Roundtable Discussion of Jennifer Lind's Sorry States: Apologies in International Politics
}

\author{
Charles L. Glaser, Thomas U. Berger, \\ Mike M. Mochizuki, and Jennifer Lind
}

How can Japan put its past behind? Scholars, journalists, and activists frequently argue that Japan cannot solve its "history problem" unless it follows West Germany's lead in offering contrition for World War II violence. Into this debate, Jennifer Lind's Sorry States: Apologies in International Politics offers an original and provocative contribution. Lind argues that while countries should acknowledge past atrocities, frequent public apologies can be domestically polarizing and diplomatically counterproductive. Sorry States outlines a theory of remembrance and threat perception and tests it in a comparative study of Japanese-South Korean and Franco-German relations after World War II. Its methods, data, and findings will interest not only East Asianists, but also scholars of international reconciliation and security studies more broadly. This roundtable presents three critical essays in addition to a response by the author. They discuss the mechanisms through which historical memory influences perceptions of threat, the relative weight of ideational versus material factors in threat perception, and whether changes in international norms and economic interdependence may increasingly pressure countries to confront past violence.

KEYWORDS: apology, memory, history, reconciliation, threat perception, Japan, Korea, Germany, World War II

\section{Historical Remembrance and International Relations Theory}

\author{
Charles L. Glaser
}

Sorry States explores the interaction between how a country remembers its history - as captured in its leaders' statements, textbooks, public 
debates, and other expressions of historical interpretation-and how former adversaries understand its intentions. The question is important for both policy and theory. There is a developing conventional wisdom that acknowledging past aggression and apologizing for it are essential for improving international relations. States that have failed to deal adequately with their violent histories have poor relations with their neighbors; consequently, goes the argument, dealing more honestly and fully with their checkered pasts is the key to a peaceful future. Germany gets high marks for having fully confronted the horrors of its Nazi past; in contrast, Japan scores poorly for having failed to apologize adequately for the violence and suffering that flowed from its efforts to dominate Asia. The difference is reflected in current political relations: Germany is not feared in Europe, while Japan is feared in Asia. On the international relations theory front, there is continuing controversy over whether a state's understanding of others' intentions even matters and little agreement about how these understandings are formed. Studying the possibility that a state's treatment of its history influences assessments of intentions sheds light on this debate.

Lind develops a theory of historical remembrance, tests it thoroughly in two cases-Japan's handling of its history with South Korea and Germany's with France- and briefly studies a few additional cases. Her theory identifies three mechanisms that could link a country's remembrance to an opposing state's assessment of its intentions. In the first, a country that deals with its history effectively sends a "costly signal." Mobilization for war often requires a state to paint its adversary as dangerous and hostile, while depicting itself as unthreatening and acting purely defensively. A state that accurately remembers its past expansionist violence undermines its ability to pursue this domestic mobilization strategy by guaranteeing that its public will question the necessity of war. Accurate remembrance serves as a costly signal because a country that anticipated launching a war of expansion would be less willing to weaken its mobilization capability than a country that planned only to respond to aggression. Second, and potentially related, states' interactions are influenced by their identities. A state that repudiates its expansionist past indicates that its values have changed and, consequently, that it can be relied upon to act differently in the future. Finally, the way a country remembers its past can have emotional effects on observers in other countries. A failure to apologize can communicate a lack of respect, which triggers anger, which in turn fuels hostility between the countries.

Lind finds partial support for the conventional wisdom on the role of historical remembrance-by denying and distorting its past revi- 
sionist behavior, a state fuels doubts about its current intentions. Having increased its assessment that the opposing state wants to revise the status quo, a state feels more insecure if the opposing state also has the power necessary to acquire offensive military capabilities. At the same time, however, Lind finds that many states have been able to form quite positive relationships without apologies for past aggression. For example, Japan has not apologized to the United States for attacking Pearl Harbor and precipitating the massive fighting that followed. Although West Germany did not deny its World War II history during the early postwar period, it also did not spend much time remembering its wartime atrocities, nor did it apologize to France during this period. Nevertheless, West Germany and France developed a positive and cooperative relationship. Thus, while effective apologies can contribute to good political relations, the evidence demonstrates they are not necessary for substantial reconciliation.

In addition, Lind's analysis of historical cases identifies a previously unappreciated risk: apologies can generate a domestic political backlash in which conservatives deny past aggression or explain it away as defensive and demanded by the state's security. This backlash then damages international political relations, which suggests the possibility that the state's relationship with its former enemy was actually damaged by the apology and ensuing domestic reactions. The apologies Japan's leaders have offered to South Korea have often had this overall negative effect. Lind concludes that countries need to strike a balance between satisfying other states' needs for its remembrance and provoking a self-defeating domestic backlash. Activists and commentators who pressure states to offer apologies have not adequately considered the possibility of domestic backlash and, consequently, may need to recalibrate their demands when backlash is likely.

Sorry States contributes to international relations theory at many levels. A key divide in the grand theory debate is over the role of a state's assessment of opposing states' motives and intentions in its choice between cooperative and competitive strategies. On one side of this debate, offensive realists argue that states should focus only on others' power, not their intentions. Given uncertainty about others' current intentions and the possibility they will change, a state cannot afford to base its strategy on the mere possibility that it faces a state that is interested only in security (Mearsheimer 2001). Defensive realists disagree, arguing that a state's strategy should depend on its information about an opposing state's motives. When the state believes that the opposing state is more likely to be a security seeker, cooperation is less 
risky, because the opposing state is more likely to reciprocate and less likely to take advantage of the state's restraint. In addition, under this information condition, cooperation is also likely to provide larger benefits, because restraint will signal that the state is itself a security seeker, which enables the state to increase its own security when facing a security dilemma. Given the central role of information about motives, defensive realism raises the question of how states assess others' intentions and, closely related, of how security-seeking states can signal their benign motives (Glaser, forthcoming; Kydd 2005). ${ }^{1}$

Clearly, Lind adds support to theories that are built on the premise that intentions matter. Her case studies consistently demonstrate both that states assess others' intentions and that these assessments influence their policies. France no longer fears Germany, an assessment that reflects its confidence in Germany's benign intentions. As a result, the continuing US military commitment to Europe is not essential for maintaining good political relations between these states, which is a striking result given that these former enemies have a long history of extremely costly wars. The role of intentions is maybe clearest in South Korea's comparison of the threat posed by Japan and the United States: although the United States is much more powerful, South Korea has viewed it as far less threatening, because it judged US intentions to be more benign. Lind does not argue that assessments of intentions dominate other factors, most obviously power, that also influence whether other states are viewed as threatening. Instead, she makes the more balanced argument that in addition to power and military capabilities, states include assessments of intentions in their evaluation of threats.

Lind's analysis bears still more directly on the question of how states assess others' intentions. Because states do rely on their assessments of motives and intentions in designing their international security policies, understanding the factors that influence these assessments is essential for both theory and policy. Scholars have already studied some of the factors that states consider in making these assessments-including, among others, regime type, ideology, and costly signals that states can send via their military and foreign policies (Owen 2001-2002; Haas 2005; Edelstein 2002; Glaser 1994-1995; Kydd 1997). Some of this information-for example, regime type-is available to a state before it interacts with an opposing state. Other factors that provide information-for example, costly signals-become available only when interaction occurs and may reflect policy choices designed specifically to communicate information about motives. 
Given the importance of understanding the factors that influence states' assessments of intentions, additional research is necessary and Sorry States makes a valuable contribution. Lind's case studies demonstrate that states carefully observe how former enemies remember their history and that this influences assessments of their intentions. France paid extensive attention to Germany's remembrance, leaving little doubt that France would have been alarmed if Germany had tried to whitewash its history. The domestic backlash generated by Japan's apologies and its efforts to whitewash some of its aggressive history fueled South Korea's distrust of Japan. As a result, South Korea worried more about Japan's military capabilities and was more fearful during periods in which Japan appeared likely to be less constrained by the United States. In short, Lind's analysis makes a convincing case for including the quality of remembrance among the factors that states rely on in forming their views of others' intentions.

Exactly how remembrance influences assessments turns out to be quite complicated. As previously noted, Lind identifies three possibilities. Her case studies and especially her identification of the importance of the potential for domestic backlash suggest a fourth possible mechanism. A domestic backlash-spurred, for example, by a state's decision about how to teach its history or by a leader's official apology-reflects the lack of a broad domestic consensus on the state's responsibility for a war and/or its actions during a war. This means that a democracy will have difficulty presenting a misleading picture of how it views its past. An apology that does not enjoy wide domestic support will be rejected by a substantial fraction of the public or elites, and opposing states will observe this domestic dispute. And as Sorry States explains, the result may be that opposing states end up more worried, not less, about the state's intentions. This conclusion is warranted, however (assuming we accept that how a state remembers and confronts its history influences its future policies). A state that is deeply divided about its history should create worries, precisely because the influence of conservative views increases the prospect that the state will eventually adopt a more dangerous distorted nationalist history. A leader's apology provides little comfort if the next election could bring to power a leader that holds diametrically opposed views. Former enemies should, therefore, be concerned not only — or maybe even primarily — with the remembrance policies that a state implements, but also with the domestic reactions they generate, because the breath of consensus may be as important as the views of the current leadership. From this perspective, acts of remembrance are not 
costly signals, but instead indicators of the breadth and stability of a country's consensus on its history. The lack of backlash demonstrates breadth, while backlash demonstrates the opposite. A liberal democracy cannot fake consensus, because it does not repress the expression of opposing political views. As a result, while a democratic state might have incentives to misrepresent its view of its own history, it will lack the ability to do so. Therefore, official statements and policies do not need to be costly to provide opposing states with valuable information; instead, the lack of a domestic backlash makes them inherently credible.

There is a parallel here to an argument about how democracy increases peace. When a government faces an opposition party, it is less able to misrepresent its preferences, because the opposition party will oppose policies that do not have support across the political spectrum. Recognizing this, and that a divisive debate will undermine its credibility in a crisis, the government will be less willing to enter into crisis bargaining that requires exaggerating its interests (Schultz 1998). ${ }^{2}$

Lind's findings also raise interesting questions about the differential impact of various forms of remembrance. Why does distorting and whitewashing one's history generate negative assessments of intentions, while failing to apologize seems not to? One possibility is that the implications for a state's future policies are different. Teaching an accurate history of past aggression may provide most of the protection that is available. As maintained by the costly signaling argument, it reduces a state's ability to mobilize for revisionist projects. Furthermore, over a sustained period, education establishes a foundation for a national consensus on a state's history that provides stability to the state's military and foreign policies, because the population's understanding of its history cannot then be quickly changed. Apologies are likely to test the strength of the national consensus-because they are the most visible, high-level acknowledgment of a state's aggressive past and of the human and political costs it inflicted-and therefore do provide information to former enemies. However, whether this is a significant addition, on top of the information provided by official histories, accurate education, and national discourses, remains an open question. ${ }^{3}$ Having shed a great deal of light on the importance of remembrance for international relations, Sorry States sets the stage for a research agenda that addresses this type of still more nuanced question.

Charles L. Glaser is professor of political science and international affairs in the Elliott School of International Affairs and the Department of Political Science at George Washington University. Before coming to George Washington, 
Glaser taught at the University of Chicago and the University of Michigan. He is the author of Analyzing Strategic Nuclear Policy (1990) and Rational Theory of International Politics: The Logic of Competition and Cooperation (forthcoming 2010).

\title{
Sorry States in a Sorry World: Beyond German Exceptionalism
}

\author{
Thomas U. Berger
}

Jennifer Lind's Sorry States: Apologies in International Politics is an important new contribution to the growing literature on the impact of apologies and restitution on domestic and international politics (Barkan 2000; Gibney et al. 2008; Nobles 2008; Torpey 2003). The cases she investigates-Germany's and Japan's relations to their neighbors-are of singular importance to world politics, and they are commonly held up as the two prime examples of what should be done-and what should not be done-to redress past wrongdoing by the state. As a result of its courageous and forthright attitude, Germany is said to enjoy healthy relations with its neighbors and to have contributed greatly to peace and stability in Europe. Japan is usually portrayed as the opposite, as a country that remains in denial about the terrible things it has done in the past, thus stirring enmity and resentment throughout the Asian region.

Lind makes three central claims in her book. First, she finds that the way in which Germany and Japan deal with their past does have a measurable impact on the degree to which they are perceived as potential threats by neighboring countries. Because of Germany's strenuous efforts to confront the dark side of its history, nations such as France and Britain no longer view it as a potential aggressor. In contrast, although Japanese leaders repeatedly have sought to apologize for their nation's history of aggression, they consistently have been undercut by powerful domestic conservative political forces who subscribe to a firmly impenitent stance on the past. As a result, Korean and Chinese elites continue to worry about the possible resurgence of Japanese militarism. Lind thus provides strong, empirically grounded support for the conventional wisdom that it is important to apologize (Lind 2008b, 154-155, 188). Lind goes on to argue, however, that contrition need not be the prerequisite for reconciliation. In the case of the Federal Republic, Lind claims that reconciliation with France preceded Germany's 
adopting a genuinely penitent stance regarding its past. Already by the early 1960s, public opinion surveys showed that a majority of the French population viewed the Federal Republic as France's most important partner in Europe, and the governments of the two countries worked together closely on a broad range of economic and security issues. According to Lind, however, German contrition regarding its past only began in earnest in the 1960s, with the entry of the Social Democrats into government after 1965 . While the French clearly cared about how Germans viewed their past, a relative lack of contrition on Germany's part did not interfere substantively with the two nations developing a productive partnership. ${ }^{4}$

Looking beyond the French-German case, Lind finds many similar instances of countries that remain impenitent regarding their past but who manage nonetheless to develop warm and productive relations with countries that were the victims of their wrongdoing. Austria, which had been a part of the Third Reich, is cited by Lind as one such example. The United States, which killed hundreds of thousands of innocent German and Japanese civilians through indiscriminate aerial bombardment during World War II, is another.

Finally, Lind warns that although not apologizing can deepen interstate suspicions, adopting a contrite stance is not without its own costs and risks. In the case of Japan, repeated efforts by successive prime ministers to apologize for Japanese colonialism and aggression have been undercut by a backlash from conservative elements in Japanese society. As a result, the goal of reconciliation in the Asian context remains an elusive one, and regional politics has been repeatedly disrupted by emotional disputes over history. Contrary to the received wisdom on the subject, it is not Japanese amnesia, but rather Japan's imperfect and repeated efforts at remembering that has been the source of so much controversy in Asia.

The practical policy implication of this line of reasoning is that governments need to weigh carefully the potential costs and benefits of apologizing for the past. While one might wish to apologize for normative reasons, and rightly done apologies may contribute to feelings of amity between two countries, if an apology triggers a nationalist backlash, it may actually damage the reconciliation process. Looking at a wide range of cases, Lind concludes that Germany is more the exception than the rule. She argues that in most countries when leaders attempt to apologize for the past, a conservative backlash is the result (Lind 2008b, 190-196). 
Lind's arguments appear eminently reasonable and are solidly backed by a wealth of empirical data. Methodologically speaking, her paired comparison of relations of countries should serve as a model for investigating these type of phenomena. All too often, the tendency has been to look at the politics of contrition solely in the context of a single country, leaving the interactive nature of the process out of the picture. One might call this the problem of "listening to the sound of one hand clapping." Moreover, the hard-nosed, pragmatic approach to dealing with the question of historical justice that Lind advocates is a welcome antidote to the reflexive advocates of contrition who feel it is always right and good to apologize and make amends for the past. ${ }^{5}$

At the same time, Lind's analysis leaves important questions unanswered. The central problem that Lind faces is that if efforts to apologize in Japan led to a counterproductive, nationalist backlash, why did they not have a similar effect in Germany? Lind is well aware of this issue, but her treatment of it is regrettably superficial, going no further than to suggest that the Federal Republic faced such enormous strategic pressures that it was possible to forge a consensus across the political spectrum in support of a sustained campaign of apology and reconciliation (Lind 2008b, 155-156, 182-183). This is undoubtedly true. However, from the 1980s, Japan as well faced considerable and growing pressures to apologize, yet a consensus in favor of contrition has proven difficult to achieve. This raises the obvious question, just how much pressure is needed to stifle a nationalist backlash, and are there any further conditions that need to be fulfilled if reconciliation is to be achieved? Lind does not tell us.

In addition, there is a certain inconsistency between Lind's argument that a nation's stance on history influences whether it is perceived as a threat and her contention that reconciliation can occur without apologizing for past wrongs. Logically speaking, if a country is viewed as a threat, it should be difficult to forge a robust cooperative relationship with that country. Lind herself seems to acknowledge as much, suggesting in various places that it is difficult to imagine European integration proceeding as it has without Germany's forthrightly taking responsibility for the crimes of the Third Reich. This is a far from trivial issue, for the European integration process-as Lind's account describes in some detail-was critical in defusing a sharp upsurge in threat perceptions that emerged at the end of the Cold War and German reunification (Lind 2008b, 140-143). If there had been no German apology, European integration would have been far weaker, and if European integration were 
not as strong and robust as it would become by the late 1980s, FrancoGerman reconciliation might well have broken down after German reunification in 1989-1991. While Germany and France might have reconciled in a limited sense in the 1960s, without the increasingly contrite German attitude toward the past that reconciliation would have proven rather fragile.

It is a pity that Lind did not pursue these questions further, for if she had, she might have arrived at a more nuanced understanding of the processes that are at work, not only in the German and Japanese cases but on a global level as well. Germany may not be as much of an exception as she believes, nor Japan as representative as she suggests of a universal pattern that when leaders apologize they trigger conservative backlashes. In fact, both countries are quite similar in that they are responding to broadly similar global processes, albeit ones that are developing at a different rate and in different ways in their respective regions. In order to understand the "sorry states" such as Germany and Japan, we have to place them in the context of the "sorry world" that has given rise to them in the first place.

That countries are pursuing questions of historical justice at the international level at all represents very much a novum in world history. In the past, Disraeli's quip "never explain, never apologize" might well be taken as the maxim by which most states conducted their foreign policies. Over the past few decades, however, a concatenation of longterm trends has placed historical justice squarely on the international agenda. The two most important ones are the development of an international human rights regime and the growth in complex interdependence between states. ${ }^{6}$

While the origins of the human rights regime can be traced back to the dawn of human civilization, it is only after World War II that standards regarding the way states should treat people were systematically codified in the form of international treaties and conventions. Initially, the human rights regime focused very much on preventing human rights abuses in the present. From the beginning, however, there was a strong historical justice component, reflected most clearly in the post-1945 efforts to punish the leaders of Nazi Germany and militarist Japan for "crimes against peace" and "crimes against humanity." Only by punishing past transgressions, it was reasoned, would it be possible to prevent their reoccurrence in the future and to create stable democratic systems in those countries. Such efforts, however, were ad hoc in nature, and the nascent human rights regime was soon crippled by the development of the Cold War. Nonetheless, over time human rights norms strengthened 
and deepened, gaining a foothold in public opinion and giving rise to an increasingly vigorous transnational human rights network (Risse et al. 1999, ch.1; Keck and Sikkink 1998). By the mid-1970s, these pressures led to changes in foreign policy making, beginning with the creation of a human rights office in the US State Department during the Carter administration. The end of the Cold War, as well as the international horror over the terrible abuses that occurred in Rwanda and the former Yugoslavia, gave further impetus to the development of human rights norms. The strengthening and deepening of the human rights regime lent legitimacy to demands from both state and nonstate actors for apologies and compensation for past human rights abuses.

Parallel to the development of the human rights regime has been the deepening of interdependence on a global scale. The growth in economic trade and investment, the increased movement of people across borders, and heightened salience of such transnational problems as pollution, organized crime, and human trafficking have increased pressures on states to find ways to build international institutions that manage and regulate the burgeoning network of linkages between them. As they do so, states become increasingly sensitive to pressures from both foreign governments and foreign nongovernmental actors on a variety of issues, including ones pertaining to historical justice. Failure to address demands for apologies and compensation can lead not only to heightened threat perceptions, but more concretely to lawsuits, economic boycotts, and diplomatic blockades in international institutions. While the growth in the international human rights regime may have enhanced the legitimacy of demands for apologies and compensation for historical injustices, increased interdependence has given such demands teeth.

The development of the international human rights regime and the deepening of complex interdependence have not been uniform processes. Some nations and some regions have been more influenced by them than others. Human rights claims have greater strength in democratic systems than they do in authoritarian ones. States that promote international trade and investment are likely to become more interdependent than others. After 1945, the Federal Republic was anchored in a Western European milieu that was largely democratic politically and highly interdependent economically. In contrast, Japan was surrounded by mostly authoritarian and totalitarian regimes, and with the collapse of the old Imperial order, intraregional trade and investment had largely collapsed. The impact of demands regarding historical justice was therefore greater on Germany than on Japan. In subsequent decades, especially beginning in the 1980s, Asia became increasingly interdependent 
and democratic (or at least more pluralistic). As might be expected, demands for historical justice grew apace.

This trend is borne out by the case of Austria, which Lind cites as evidence that reconciliation can develop without contrition. For much of the Cold War, Austria was resolutely impenitent for the role it played in the Holocaust. If anything, Austria was even less willing to confront the dark side of its recent history than was Japan. Yet, as Austria became increasingly integrated into the European Union, the pressures on it to apologize escalated. After the end of the Cold War, as Austria contemplated joining the European Union, Austria's leaders concluded that it had no choice but to undertake a campaign of apology and reconciliation. While that stance was challenged by the ascent of Jorg Haider and the Freedom Party, even Haider was forced to capitulate on the history issue after joining government in 2000. Since then, Austria has moved quickly in the direction of official penitence, rivaling Germany in the depths of the contrition that it exhibits. ${ }^{7}$

The point here is not the classical liberal argument that increased regard for human rights (ultimately leading to democratization) and interdependence decrease threat perceptions. That may be true, but it is not the argument that I am trying to make here. Rather, what I am arguing is that the advent of the international human rights regime and the deepening of interdependence have reshaped the politics of history by strengthening demands for apologies and other forms of redress for historical injustices. Whether these forces are powerful enough to make strategic arguments for offering apologies sufficiently compelling to warrant the costs and risks of doing so depend on a variety of other factors, including regional and domestic politics.

In this context, there remain clear differences between East Asia and Western Europe that both encouraged and allowed Germany to apologize successfully to its neighbors. One of the main reasons that Germany was able to develop a deeper and more robust reconciliation with its neighbors was because there was considerable European receptivity to German efforts. For reconciliation to occur, apologies must not just be given; they also have to be accepted. While some Asian leaders-most notably Kim Dae-jung of South Korea in 1998-have responded positively to Japanese efforts, others have not. Often, this lack of receptiveness is reflective of the weakness of Asian governments. In both South Korea and China, leaders have periodically made use of anti-Japanese sentiment to bolster their own legitimacy. In addition, appearing too close to Japan has often been a political liability, as Hu Yaobang discovered to his cost in China in the 1980s and as Presi- 
dent Lee Myun-bak of Korea has learned again today. ${ }^{8}$ The much more stable democratic, highly interdependent Western European states have had far less difficulty in this respect. As Eastern Europe also is integrated into the European system, there are signs that a similar process is taking place there as well. ${ }^{9}$

There is nothing inevitable about these trends. Human rights concerns can be ignored even by solidly democratic societies. Interdependence can lead to conflict as well as cooperation. Together, however, increased interdependence and democratization has made historical justice issues more salient than in the past. They create powerful incentives for governments to try to mange them, lest they seriously disrupt relations between them-as they did in Austria's ties to the European Union in the late 1980s and in 2000, Japan's relations with Asia during the Koizumi administration, and Turkey's relations with Europe today. Rather than ignore the history issue, as Lind seems to suggest, nations need to develop a pragmatic diplomatic strategy for dealing with tensions over history when they arise, based on calculations of their national interest and calibrated with a cool appraisal of the possibilities for success. Even when the prospects for success are poor in the short run-as appears to be the case in Asia today-leaders need to try to lay the groundwork for reconciliation based on apologies and the recognition of historical wrongs. Given the sorry nature of the modern world, sooner or later it seems likely that we all will be sorry.

Thomas U. Berger is associate professor in the Department of International Relations at Boston University. He is the author of Cultures of Antimilitarism: $\mathrm{Na}$ tional Security in Germany and Japan (1998) and coeditor of Japan in International Politics: Beyond the Reactive State (2007). He is currently working on a manuscript on the politics of memory viewed from a comparative perspective.

\title{
Remembrance, Realism, and Reconciliation in Northeast Asia
}

\author{
Mike M. Mochizuki
}

The impact of collective memory on international security is often asserted but rarely receives systematic examination. Jennifer Lind's Sorry States is therefore a welcome addition to the literature on memory and reconciliation in Northeast Asia. Her core argument is that remembrance 
matters for security because it can shape threat perceptions and the level of trust between countries. However, to her credit Lind considers the impact of four other variables that might also affect threat perceptions, including institutional membership, regime type, territorial claims, and capabilities. Lind's examination of the Japan-South Korea dyad suggests that the key alternative causal factor to the remembrance variable is the "capabilities" variable. Drawing on realism, she defines capabilities as "the power that one state can bring to bear against another." In addition to potential and mobilized material capabilities, she includes in her concept of capabilities the notion of "constraints," which are external factors (e.g., the presence of an occupier, "offshore balancer," a balancing coalition, or other threats) that check a state from applying its material capabilities against another state.

Dividing Japanese-South Korean relations into three time periods enables Lind to make three sets of observations across which both the independent and dependent variables vary somewhat. In the 1952-1964 period, the Japanese neither remembered nor regretted their country's past violence in Korea. A wide gap in material capabilities existed between Japan and South Korea, while South Koreans had doubts about the persistence of the US-Japan alliance as a constraint on Japanese power. As expected, the author finds that South Koreans distrusted and feared Japan during these years. But because the remembrance and capabilities variables point in the same direction, it is difficult to determine whether either variable is necessary or sufficient to explain South Korean perceptions of Japan.

The two later periods offer a better test of the relative power of remembrance and capabilities as explanatory factors. During the 1965-1989 period, Japan began to offer tepid apologies, but denials of past atrocities remained widespread. In terms of capabilities, however, not only did the material gap between Japan and South Korea begin to narrow, but also the US security commitment in Northeast Asia was robust enough to constrain Japanese power and protect South Korea. Since the 1990s, Japan has much more embraced apologetic remembrance, but this trend is undermined by a nationalistic backlash of denials and justification of past violence. But the Japan-South Korea capabilities gap has narrowed even more; and Japanese power continues to be constrained by a reinvigorated US-Japan alliance. In both periods, Lind finds that while Koreans continued to distrust the Japanese, they did not have an elevated perception of a Japanese threat. In fact, the South Korean government embraced security cooperation with Japan and even endorsed a more active Japanese defense policy. 
The capabilities factor, therefore, appears to trump remembrance in shaping South Korean threat perceptions of Japan. Lind indeed admits that a strong version of her remembrance theory does not hold up: "Unapologetic remembrance will elevate threat perception regardless of other signals" (Lind 2008b, 94-95). She claims, however, that the evidence confirms a weaker version of her theory: "Countries weigh remembrance just as they evaluate other signals of intentions and threat." Lind insists that "process tracing" based on documents, interviews, and newspaper accounts demonstrates a causal link between remembrance and threat perceptions: "Denials elevate threat perception." But in her empirical analysis, she often asserts that while Japanese denials have caused South Koreans to mistrust Japan, strategic constraints have caused South Korean elites not to view Japan as a threat. In other words, even if Japan's remembrance is unapologetic, the US alliance commitment to Japan and South Korea has been sufficient to explain why South Korea views Japan as relatively nonthreatening.

How does Lind's remembrance theory fare regarding the West Germany-France dyad? During the early postwar period (1945-late 1950s), while acknowledging Nazi crimes, West Germans felt little responsibility for them and were focused on their own suffering rather than being apologetic toward others. Despite this amnesia, West GermanFrench reconciliation advanced significantly and the French developed benign views of its former adversary because of other more critical factors: French advantages in mobilized power, the constraint on West German power through foreign occupation and NATO, West German membership in European institutions, and the fact that both countries consolidated their postwar democratic regimes. More recently-during the period 1965-1989 and from the 1990s to the present-West Germany (and later reunited Germany) has embraced apologetic remembrance, but the other factors continued to operate to sustain French positive views of Germany. In short, the absence of French fears of Germany is overdetermined. Lind's comparison of the Japan-South Korea and West Germany-France dyads indicates that traditional realist factors may matter more than memory for threat perceptions.

But what are we to make of Lind's implicit realism? First, it is worth noting that her analysis of capabilities and constraints runs counter to existing realist analyses of Japan-South Korea relations. For example, contrary to Lind's claim that uncertainties about the US alliance elevate South Korean threat perceptions of Japan, Victor Cha (1999) argues that when US security commitments in Northeast Asia appear to be uncertain, fears of abandonment have driven Japan and 
South Korea to put aside history-related disputes and promote their common security interests. Cha's analysis encourages us to consider realist variables as promoters or inhibitors of reconciliation.

Second, by focusing on apologetic remembrance as a costly signal for reassurance, Lind does not consider enough the relative effect of other reassurance signals. Japan adopted during the 1960s and 1970s numerous self-imposed constraints on its security policies even while pursuing defense modernization: the three non-nuclear principles, a ban on arms exports, a 1 percent GNP ceiling on defense spending, a strictly defensive doctrine, and preservation of Article 9 (the so-called peace clause) of Japan's postwar constitution. Although these constraints were imposed in large part to appease an antimilitarist public and pacifist opposition parties, it would be surprising if these constraints did not also send reassuring and even costly signals to Japan's neighbors. Although Lind treats the US alliance as the primary constraint on Japanese capabilities vis-à-vis South Korea, Washington's frequent accusation about Japanese security free riding shows that the self-imposed policy constraints added to the external constraint of the alliance. This reassurance from Japan's constrained security policy partially compensated for the lack of apologetic remembrance (Midford 2002).

This relationship between security and historical reassurance reveals how memory and reconciliation may really matter for security. The problem with the time frame that Sorry States covers is that the abundance of constraint from the strategic environment and Japan's own security policies diminishes remembrance as a factor on South Korean threat perceptions. But remembrance about the past may ultimately matter most through the shadow it casts on the future. Since the end of the Cold War, Japan has been incrementally relaxing its heretofore self-imposed constraints on its security policy. Of course, Japan has a long, long way to go before becoming a great power with nuclear weapons, and immense political obstacles to a revision of Article 9 of the constitution remain. Nevertheless, the fact that those in Japan who are most vigorous in promoting a more assertive security policy tend to be those who are least apologetic about the past should not be very reassuring to South Korea.

If the original Cold War conflicts of Northeast Asia (in Korea and across the Taiwan Strait) eventually move toward reconciliation or even resolution (e.g., Korean reunification), US strategic policy and military posture in East Asia will inevitably undergo a fundamental reassessment that could weaken their constraining effect on Japan, thereby increasing 
the causal salience of remembrance. As Lind writes, "Because Japanese intentions are so deeply mistrusted (in great part because of their repeated denials about the past), Japan's neighbors would worry about the growth of Japan's freedom and power if the United States were to leave the region" (Lind 2008b, 188). Moreover, the shifting power balance in East Asia with China's rise will also compel strategic adjustments that could trigger vexing security dilemmas. Identifying and achieving a configuration of state policies that optimize regional security and stability are difficult enough during power transitions. Emotional conflicts about the past will further complicate this task, not to mention East Asian community building advocated by many in the region. The experience of German reunification in Europe is instructive. Despite decades of progress in historical reconciliation, the French initially expressed concerns about German reunification (Lind 2008b, 139-140). Imagine how problematic reunification could have been without reconciliation. Because Korean reunification and China's rise together pose a more demanding challenge of strategic adjustment for Northeast Asia than German reunification did for Europe, progress in historical reconciliation will be even more critical in Northeast Asia.

So what is to be done? Asian critics of Japan often insist that Japan should be more like Germany, but Lind warns against trying to emulate Germany. In her view, Germany is quite exceptional. After being amnesiac in the early postwar period, West Germany became stridently apologetic beginning in the 1960s. But what makes the German case unusual is the absence of a strong nationalistic backlash against apologetic remembrance. By contrast, Japanese apology initiatives that began in the 1980s triggered a powerful backlash that undermined the positive impact of these initiatives. What explains the difference? To explain the German anomaly, Lind invokes a realist logic by referring to Germany's postwar strategic situation (Lind 2008b, 183). Because of their quest for national reunification, West German conservatives had "a strong disincentive" to protest contrition. But the same logic might also apply to Japanese conservatives who favor rearmament. Therefore, a more complete explanation of the German-Japanese difference demands a closer look at domestic politics.

After World War II, Japanese like Germans were fixed on their own victim narratives. But by the 1960s, again like in Germany, progressive intellectuals and leftist political organizations in Japan pushed a perpetrator narrative that highlighted their country's war guilt. They used the judiciary to try to compel the Education Ministry to permit more explicit descriptions of Japanese militarism in school textbooks, and they 
blocked attempts by the conservative ruling party to renationalize the controversial Yasukuni Shrine. But these forces were not powerful enough to alter state policy to embrace unequivocally apologetic remembrance or to establish a national consensus behind a public discourse of contrition. Therefore, the reluctant steps toward contrition that were taken from the mid-1960s through the 1980s were primarily a result of foreign pressure rather than domestic political change. Washington pressured Tokyo to offer the tepid 1965 "apology" to South Korea so that Japan and South Korea could conclude their exasperating negotiations for a normalization treaty. The need to appease China during the 1972 normalization talks prompted an ambiguous apology statement. Chinese and Korean protests during the 1982 textbook controversy compelled Japan to alter its textbook guidance; and comparable protests caused Prime Minister Yasuhiro Nakasone to refrain from further pilgrimages to the Yasukuni Shrine after his August 15, 1985, "official" visit.

Only after the fall from power in 1993 of the conservative Liberal Democratic Party (LDP) did Japanese apologies become more forthright. After becoming the first prime minister of a non-LDP government since the LDP's formation in 1955, Morihiro Hosokawa, unlike his predecessors, candidly acknowledged Japan's war of aggression; and during his trip to South Korea, Hosokawa gave an apology to South Korean president Kim Young-sam that went far beyond the halfhearted apology of 1965. It was the Socialist prime minister Tomiichi Murayama who issued in August 1995 the gold standard of Japanese official apologies and established the Asian Women's Fund as a pathbreaking public-private effort to compensate comfort women for their suffering and establish awareness programs.

What made these reconciliation efforts vulnerable to a nationalistic backlash was that they either were motivated by foreign pressure or lacked robust and sustained domestic political backing. Hosokawa resigned in April 1994 after being prime minister for less than eight months because of a corruption scandal, and the LDP was back in power in June 1994 by forming an "unholy" coalition with its ideological adversary, the Socialists. Murayama tried to get the National Diet to pass a resolution that would acknowledge and apologize for Japan's past aggression, but conservative parliamentarians so diluted the resolution's wording that it provided further evidence of Japanese denials. Miraculously, Murayama was able to get his coalition cabinet to endorse his August 1995 statement by forcing the issue without substantive discussion. 
The German experience could not have been more different. The awakening of West German contrition transpired with the ascendancy of the Social Democrats in the 1960s led by politicians like Willy Brandt who had long favored a more vigorous embrace of apologetic remembrance. The Social Democrats, by being in power from 1966 to 1982 and by working with nongovernmental actors, succeeded in transforming public discourse in favor of contrition and remembrance of past war crimes. By the time the conservative Christian Democrats returned to power in 1982, a national consensus behind apologetic remembrance had taken root. Whereas Japanese conservatives charged that education about past transgressions was a form of masochism, conservatives and social democrats alike in Germany came to believe that such acknowledgment should be a matter of national pride. Not only did no major nationalistic backlash emerge in Germany, but also Germans became more receptive to a broadening of societal responsibility for Nazi crimes (Art 2006).

So to enable Japan to follow the German example, what is probably necessary is a prolonged period of center-left governments that would be dedicated to the task of historical reconciliation and transformation of public discourse about history. In the August 2009 House of Representatives election, the Democratic Party of Japan (DPJ) defeated the LDP in a landslide victory. Since DPJ parliamentarians tend to acknowledge Japan's past aggression and atrocities much more unequivocally than their LDP counterparts, the rise of the DPJ to power presents the best hope yet that public discourse about the past can finally change in Japan as it did in Germany. But there are nationalistic deniers in the DPJ who might collude with elements in the LDP to block apologetic remembrance initiatives. Moreover, if the DPJ-led government is short-lived, a successor conservative government could overturn or undercut DPJ apologetic remembrance initiatives and cause even more damage. Therefore, I agree with Lind that the German path to reconciliation may be both too ambitious and too risky for Japan.

What are we then left with in terms of prescriptions? Lind states that "while modest gestures of contrition (e.g., a basic acknowledgment of past misdeeds) reduces threat, greater contrition has no reliable beneficial effect and can in fact worsen relations if it triggers domestic backlash (Lind 2008b, 185). She therefore advocates "a middle ground between whitewashing and contrition" whereby leaders shift away from accusations and apologies and "structure commemoration to cast events-as much as possible - as shared catastrophes." As an example, she offers the 1984 ceremony at Verdun Cemetery during which François Mitterrand and Helmut Kohl held hands as they remembered 
700,000 French and German casualties of that greatest of World War I battles (Lind 2008b, 191). One is, however, hard-pressed to identify a comparable commemorative event that might resonate with both Japanese and Koreans or with both Japanese and Chinese. Moreover, I suspect that the Verdun gesture had the positive emotional effect because of (and not in place of) the decades of German apologetic remembrance about World War II that had preceded the 1984 commemoration.

In her Foreign Affairs article, Lind (2009) offers another prescription. Although she invokes the concept of "apologetic remembrance" throughout Sorry States, she also distinguishes between remembrance (i.e., acknowledgment of past atrocities) on the one hand and acts or statements of apology/contrition on the other. She claims that remembrance/acknowledgment is sufficient and that apology/contrition is unnecessary and risky because it might trigger a backlash. In the Foreign Affairs article, she builds on this distinction to recommend that Japan follow the example of West Germany's Konrad Adenauer rather than Willy Brandt. Rather than being contrite as symbolized by Brandt's famous 1970 "Warsaw genuflection," Japan should follow Adenauer's example of acknowledging Germany's wartime aggression and atrocities and paying reparations. But the Adenauer example does not work for Japan either, because Lind's distinction between acknowledgment and apology is unsustainable in operational terms. The nationalistic backlash in Japan is a backlash against not only apologies but also acknowledgment and compensation. Japanese revisionists challenge the history about which Koreans and Chinese seek unequivocal Japanese recognition: colonial brutality, aggression, and atrocities.

While the Japanese domestic backlash of denial is what usually provokes Koreans and Chinese to lash back at Japan, reconciliation ultimately has to be a two-way process. We must therefore examine domestic politics in South Korea and China as well. The sharp political divide in South Korea between authoritarian modernizing elites who forged the normalization agreement with Japan in 1965 and prodemocratization forces that opposed their country's authoritarian rulers and criticized their collaborationist roots impeded Korean-Japanese reconciliation at the societal level. After South Korea's democratization, the unleashing of nationalistic nongovernmental organizations and social movements made it difficult for Koreans to recognize and graciously accept well-intended reconciliation efforts like the Japanese Asian Women's Fund, thereby undermining the domestic credibility of Japanese advocates of realistic redress and remembrance initiatives. By taking up the issue of Japanese-Korean collaboration during the colo- 
nial era for the purpose of democratic consolidation as well as domestic political expediency, the Roh Moo-hyun government exacerbated history-related disputes between Seoul and Tokyo. In China, elite mythmaking and patriotic education campaigns stoked anti-Japanese sentiments in society that exploded in the unruly demonstrations against Japan in spring 2005 (He 2007).

After the Northeast Asian "memory wars" of 2001-2006, fueled in large part by Prime Minister Junichirō Koizumi's repeated pilgrimages to the Yasukuni Shrine, economic interests, security calculations, and domestic political concerns drove leaders in Tokyo, Seoul, and Beijing to forge a delicate truce. Koizumi's successors have refrained from visiting Yasukuni; and Japan, South Korea, and China have resumed regular summits and avoided inflaming conflicts about history. This ceasefire in the memory wars provides an opportunity to construct in a less politically charged atmosphere what Lind calls "a shared and nonaccusatory narrative between nations" (Lind 2008a). How might this be done?

Since nations themselves are often divided about memory and professional historians will inevitably disagree about historical explanation and interpretation, a quest for historical agreement across countries is both illusory and undesirable. The aim instead should be what Susan Dwyer $(1999,88-89)$ aptly terms "narrative incorporation" to establish a "narrative equilibrium" between former adversaries. A process of realistic reconciliation as sketched by Dwyer might entail the following steps. First, by releasing, collecting, examining, and evaluating evidence (written documents, oral histories, and photographs), an effort would be made to establish the "barest of facts," discredit the obvious falsehoods, and distinguish between fact and interpretation. Next, based on this systematic inquiry of the empirical evidence, the range of plausible historical explanations and interpretations would be narrowed. Finally, rather than negotiating a single interpretation, the goal would be to identify "a limited set of interpretations" that would be mutually tolerable. Former adversaries would share a range of different historical views about which they can agree to disagree; and the lines of debate and disagreement may eventually transcend nationality with greater frequency.

Even this more limited goal of narrative incorporation and equilibrium is a daunting task. The officially sanctioned joint history research committees formed between Japan and South Korea in 2002 and between Japan and China in 2006 will certainly contribute to this task. But the shortcoming of government-sponsored dialogues is that they 
can induce political posturing among their participants. Therefore, unofficial, private-based dialogues must supplement these official commissions. Starting with historians and social scientists makes sense, but these dialogues should be broadened to include educators, journalists, NGO activists, religious leaders, filmmakers and writers, politicians, and other societal actors. To promote such activity both bilaterally and multilaterally, a thick regional web of institutions must be established similar to that which facilitated reconciliation in Europe. Thankfully, there has been some progress in this regard in Northeast Asia, but the institutional network remains woefully thin compared to Europe. The deep reconciliation that exists today in Western Europe resulted from decades of painstaking effort as well as visionary leadership. Therefore, the current lull in the Northeast Asian history disputes should not foster complacency. Now is the time to invest in reconciliation before the strategic constraints on potentially threatening capabilities that Lind ably analyzes loosen, making Japan's unapologetic remembrance more problematic for regional security.

Mike M. Mochizuki holds the Japan-US Relations Chair in Memory of Gaston Sigur at the Elliott School of International Affairs of George Washington University and codirects the Memory and Reconciliation in the Asia-Pacific project of the Sigur Center for Asian Studies. He is currently completing a book titled A New Strategic Triangle: The U.S.-Japan Alliance and the Rise of China and coediting a book titled Reconciling Rivals: War, Memory, and Security in East Asia.

\title{
Sorry States and the Research Program on Memory and International Politics
}

\author{
Jennifer Lind
}

Hollywood lore has it that after Fred Astaire's first screen test, the director jotted down the following notes: "Can't act. Slightly bald. Can dance a little." The three scholars who generously agreed to participate in this roundtable were far kinder to me: while they saw ways in which my book stumbled, they also praised some of its footwork. The thoughtful commentary by Charles Glaser, Thomas Berger, and Mike Mochizuki raises four key questions that I address below. 


\section{Does Remembrance Matter?}

Mochizuki throws down the realist gauntlet by questioning whether remembrance actually affects threat perception and reconciliation. Mochizuki argues that the variable of military capabilities is sufficient to explain threat perception in East Asia and suggests that the book's claims about the power of remembrance are undermined by its "implicit realism."

Sorry States contends that the ways in which states remember past violence shapes other countries' perceptions of their intentions. The book argues that Japan's denials and glorifications of atrocities fuel South Korean distrust. Koreans, however, do not perceive a security threat from Japan because they recognize that its power-while formidable-is highly constrained. Apprehensive about Japan's intentions, Koreans worry about a future in which those constraints might loosen.

In its analysis of the Japan-South Korea case, Sorry States thus concurs with Mochizuki's argument that capabilities "trump remembrance in shaping South Korean threat perceptions of Japan" and that in this and many other cases, "traditional realist factors may matter more than memory for threat perceptions." Far from challenging my argument, this is my argument (Lind 2008b, 93-94). Far from implicit realism, this is explicit realism. Glaser clarifies as much, as he situates the book comfortably within the defensive realist tradition. ${ }^{10}$

However, capabilities do not tell the whole story. South Korea does not perceive a military threat from Japan, because it is tied down with a thick chain. The chain is thus critical to this story-but the story is incomplete until we also understand why Koreans want to see Japan tied up in the first place. Sorry States presents extensive process-tracing evidence showing that Koreans distrust Japan's intentions, and that people directly connect their distrust to Japan's denials of past atrocities. Koreans worry that Japan's failure to repudiate the havoc it wreaked in the twentieth century reveals a potential willingness to wreak havoc in the twenty-first.

Later in his essay, Mochizuki seems to agree with all of this. Completely in accord with my argument (Lind 2008b, 188), he notes that latent distrust of Japan caused by the history issue will become salient if the United States withdraws its military forces from the region. He clearly agrees that remembrance has important effects on threat perception in East Asia - in other words, that capabilities do not tell the whole story. 


\section{How Much Contrition Is Necessary?}

Sorry States offers a great deal of evidence that denials of past violence elevate distrust between countries. States facilitate international reconciliation when they acknowledge past aggression and atrocities. But the more contrition they offer, the greater the risk of a domestic backlash that alarms outside observers.

Berger makes the case that states should offer more contrition than Sorry States prescribes. He argues that I have understated just how contrite West Germany was in the 1950s and that I understated the impact of this contrition on European reconciliation. But contrary to the notion that I have understated the impact of German remembrance in the 1950s, I explicitly argue in Sorry States and elsewhere that it is a model other states should follow (Lind 2009). Berger and I agree that Bonn's remembrance in the 1950s reassured Germany's former adversaries and eased reconciliation.

As for the extent of German contrition during this decade, I dispute Berger's claim that in the 1950s there was "considerable engagement by all levels of German society" with the past. West Germany acknowledged its past violence in numerous ways: Bonn offered an apology (albeit a rather self-exculpatory one) to Israel in 1952 and began paying reparations during this decade. Perhaps most important is that mainstream leaders did not deny Germany's terrible violence. But West Germans also resisted contrition (Lind 2008b, 108-114). Reparations to Israel were deeply unpopular, fought by a large majority of the public and by Chancellor Konrad Adenauer's own cabinet and party - half of which abstained from the Bundestag vote. West German leaders felt that legal trials would be divisive and should be avoided; scholars note that "legal attempts to deal with the legacy of the [Nazi] past were sluggish in this period and soon came to a halt" (Knischewski and Spittler 1997, 241). Historians explored German suffering during World War II or averted their gaze to prouder times. Textbooks glossed over the recent past. The vast majority of West Germany's legendary contrition came in the 1960s, 1970s, 1980s, and later: the dramatic public apologies, the extensive textbook coverage, the contrite museums and memorials, and so on. These later efforts to come to terms with the past were clearly unnecessary for a reconciliation that had begun many years before. ${ }^{11}$

Berger also argues that countries will have to be more contrite in the future because of two trends: the growth of a human rights regime and complex interdependence. According to his view, states face more 
and more demands for contrition (fueled by growing attention to human rights), and states that do not meet those demands pay higher and higher costs because their prosperity depends on trading partners and international institutions.

This intriguing hypothesis should be explored further. Liberal democracies are indeed less and less likely to either practice chest-thumping nationalism or to tolerate it within their neighbors (Kennedy 1970). Scholars should investigate the international political effects of this trend. Future work may indeed show that international pressure has pushed some countries toward penitence, and that a national desire to satisfy multilateral institutions and align with global human rights norms prevented a backlash.

At this point, however, I wonder just how much evidence supports Berger's claim that rising interdependence has given demands for contrition "teeth"? Japan continues to be impenitent, yet has paid no significant economic costs for this. The Chinese and South Koreans fumeand keep trading. Boycotts are rare and ineffectual, sanctions nonexistent. Many of the countries I discuss in Sorry States (pp. 183-185) are supportive of human rights norms, deeply enmeshed in the global economy - and deeply unrepentant of past violence.

\section{When Does Contrition Cause Backlash?}

Sorry States uncovers a puzzle: why did attempts to offer contrition in Japan and many other countries trigger intense domestic controversy, and yet Germany's far more extensive apologies did not cause significant backlash? Answering this question matters because if backlash can be avoided, contrition can be a useful tool of justice and reconciliation. But if efforts to apologize prompt backlash, they will antagonize rather than soothe international relations.

In Sorry States I argue that backlash will be a predictable response to contrition, particularly within democracies. Conservatives might oppose apologies for philosophical reasons: many believe that a strong polity requires citizens to have a deep love of country, which is undermined by rummaging around in skeleton-filled closets. Or, politicians may simply oppose contrition because they believe that doing so is an expeditious strategy for winning elections. For every penitent citizen who wants to honor foreign victims, there are another two (ten? hundred? thousand?) voters who want to honor the sacrifices of their dead fathers and grandfathers. Opportunistic politicians will pander to voters 
and amplify those feelings. The dynamics of democratic political competition thus make backlash to contrition a predictable phenomenon.

So when doesn't backlash occur? Mochizuki argues that domestic politics explains what caused backlash in Japan and silenced it in Germany, but this hypothesis is unsatisfactory. Domestic politics may indeed explain why states decide to apologize-namely, when electoral victories or strange twists of coalitional fate empower the left. But Mochizuki's argument does not explain why liberals can sometimes apologize without provoking backlash. He writes that Japanese contrition sparked backlash because such contrition was "motivated by foreign pressure or lacked robust and sustained political backing." The latter point, however, is tautological (i.e., there was opposition to contrition because there was little support for contrition). The former point is certainly possible but is unsubstantiated and undercut by episodes of backlash that occurred in the absence of foreign pressure (for example, Japan's 1995 Diet resolution and the Enola Gay controversy in the United States that same year).

Berger argues that Europe's higher levels of human rights and democratization versus the lower stages of development of these factors in Asia explain why backlash was so much more intense in Japan than in West Germany. As already discussed, the impact of these trends merits further scholarly attention. One notices, however, that the internal logic of this hypothesis is somewhat strained. Understanding what muted backlash in West Germany means understanding what motivated West German conservatives, not liberals. Although the Social Democrats may indeed have perceived themselves as part of a global human rights movement, West German conservatives were hardly ambassadors of "flower power"- and it is their decisions, after all, that we seek to explain.

More important is that Berger's hypothesis about the potency of human rights norms and complex interdependence sits uncomfortably with a great deal of disconfirming evidence. US interdependence did not silence bellows of backlash during the 1995 Enola Gay controversy. If Barack Obama fell to his knees in Hiroshima, he would unleash a tempest at home: not only from Congress but from Americans across the country who lionize the "greatest generation." Britain is as interdependent as anybody, and yet proposed British apologies for violence in Ireland and for its role in the global slave trade elicited backlash. Japan's prosperity has long depended on its deep integration with the global economy, and Berger, Mochizuki, and I all have commented on the strength of backlash there.

As I argue in Sorry States, the absence of backlash in West Germany seems powerfully related to its strategic situation. Germany was 
ripped in half. Bonn cowered in the long shadow of the Soviet military threat, and the only people the West Germans could call for help were the very people they had been killing fifteen years earlier. Perhaps West Germans also wanted to be in accord with global human rights norms. But what was at stake was very literally the survival of the German state. To survive, and someday to reunite, West Germans could not confirm the sneaking suspicions of their new allies - they had to admit German crimes and distance themselves from Nazi policies. By standing up and defending Adolph Hitler, West German conservatives would have jeopardized their most important goals. ${ }^{12}$

Japan's strategic situation after the war was quite different. Pointed west, not east, the Soviet military threat was further buffered by Japan's wide moat. Tokyo was allied with a superpower that cared not a fig for Japanese apologies: for Japan, the Cold War means never having to say you're sorry. The Chinese cared, but let Japan off the hook, because at the time they cared more about luring Japan away from the United States and winning its support vis-à-vis Taiwan (He 2007). The Koreans have cared all along, but Japan had no desire or imperative to snuggle with South Korea: it added little to the power of Japan's extant alliance, and brought a horrendous risk of entrapment. In sum, Japan's strategic environment did not compel it to remember the wrongs it had committed against its neighbors: its conservatives had no reason to bite back their natural objections to contrition.

Studying the conditions that mute or exacerbate backlash is necessary to understand the utility of contrition as a tool of international reconciliation. Scholars may begin to understand how backlash varies across space, and-following Berger's lead-may discover that it varies over time. At this point, Sorry States offers strong deductive and empirical grounds for caution. Advocates promote contrition as a cure for historical enmity, but the first clinical trials are in, and most of the test subjects got sicker. It seems a particular violation of the Hippocratic oath to keep prescribing this drug to the test subject (we'll call him "Japan") who gets sick after each dose. The evidentiary burden must shift to the advocates of contrition.

\section{How Does Remembrance Affect Reconciliation?}

In Sorry States I outline three possible mechanisms that connect remembrance and international reconciliation. As Glaser summarizes, I hypothesize that remembrance affects reconciliation because it affects 
domestic mobilization; because it conveys information about the identity of a state; or because it affects the emotions of observers. Glaser proposes a fourth mechanism, insightfully wondering whether remembrance affects reconciliation precisely because of the backlash it does or does not create. Scholars have previously thought that it is the acts of contrition themselves that cause reconciliation: that apologies, monuments, reparations, and so forth send signals about the state's intentions that in turn reduce threat perception and promote reconciliation. But in Glaser's view, such acts may not be the point at all; the point is the domestic reaction they elicit. Contrition, in essence, is a poll: a question thrown out into the political marketplace. The danger is that it's a very public poll; the international community will hear the debate when perhaps it would have been better had they not.

As any good politician knows, never conduct a public poll unless you know the answer already-and you know that answer will be favorable to you and your interests. Sorry States warns that more often than not, (1) this poll will produce some disquieting information, and (2) this information will have real and detrimental effects on foreign relations. I argue that rather than offering potentially divisive apologies, states would better advance the goal of reconciliation by acknowledging past violence but adopting a forward-looking approach. As Mochizuki explains, countries have numerous unofficial forums in this highly interconnected world in which their people can promote progress in historical reconciliation and shed light on the past while minimizing destabilizing backlash.

Jennifer Lind is assistant professor in the Government Department at Dartmouth College. In addition to her book Sorry States, she has published articles about East Asian international security in Security Studies, International Security, and Foreign Affairs. Her current research examines the future of the Korean peninsula and the stability of the East Asian region.

\section{Notes}

1. Waltz (1979), which presents the seminal statement of structural realism, does not fit neatly into either but pays little attention to states' intentions, so in this regard it is similar to offensive realism. Brooks (1997) argues that Waltz's analysis requires states to make worst-case assumptions. On the related question of the role of perceptions of intentions in states' assessments of threats, see Walt (1987). 
2. See Schultz $(1998,830)$, who argues that "a government with a domestic competitor has less opportunity to misrepresent its preferences, and the dangers associated with asymmetric information are consequently lower."

3. For a thoughtful discussion of the nature of apologies and of how international and interpersonal apologies differ, see O'Neill (1999).

4. It is possible here to challenge Lind's depiction of the development of German contrition. There is little doubt that during the 1940s and 1950s there was a powerful social and political tendency to try to put the past behind Germany. Nonetheless, the scholarly consensus is that by the late 1950 s there was considerable reengagement at all levels of German society with the issues of the past. By certain measures - that is, pursuit of war criminals and the payment of large sums of compensation to victims of Nazism-already in the 1950s Germany was far more contrite than Japan was even in the 1990s. In addition, resistance to German contrition persisted far longer than Lind's account would allow for. As late as 1970, a plurality of German public opinion was critical of Brandt's dramatic falling to his knees before the Warsaw Ghetto monument; 48 percent thought it was exaggerated, as opposed to 41 percent who thought it appropriate. Arguably, a consensus across the political spectrum on the need for a genuinely penitent stance on the Nazi past did not emerge until the mid-1980s. For a good, concise overview, see Kansteiner (2006). Contrary to Lind's claim that reconciliation preceded contrition in the Franco-German case, in reality German contrition tracked the diminishment of French threat perception quite well. Early German contrition in the 1950s helped pave the way to Franco-German reconciliation in the late 1950s and 1960s. The deepening of German contrition in the 1960s through the 1980s may have helped increase French and British confidence in the reliability of Germany as an ally and partner, enabling Europe to weather the shock of German unification between 1989 and 1991.

5. Lind's work may be seen as part of a larger movement skeptical of the putative benefits of pursuing historical justice issues (Snyder and Vinjamuri 2003; Ron and Thoms 2007).

6. On the development of the international human rights regime, see Lauren (2003) and Hunt (2008). The locus classicus for the concept of complex interdependence is Keohane and Nye (1977).

7. Unlike Japan, Austria has offered substantial sums of compensation for former slave laborers, has become a leader in repatriating stolen art treasures, and has officially sponsored museums and monuments that commemorate its role in the Holocaust (Art 2006; Pick 2000).

8. On Hu Yaobang, see He (2009, 273-276). The author would like to thank Professor He for making the manuscript available to him. For Korea, see President Lee Myun-bak's recent problems regarding the disputed Takeshima/ Dokdo islands, "Apology for Offer to Sell Dokdo," Korea Times, May 29, 2009, available at www.koreatimes.co.kr/www/news/opinon/2009/04/170_ 24974.html.

9. In light of the previous analysis, it is not surprising that German reconciliation with the recently democratized nations of Eastern and Central Europe 
has been far rockier than its relations with more established EU members in the West. The rise of narratives of German victimization since the late 1990s has provoked severe diplomatic tensions, particularly between the Federal Republic of Germany and Poland and Czechoslovakia. Yet, even in these cases, it has been possible to defuse tensions, and public opinion data show that threat perceptions regarding Germany have not increased (Falkowski and Popko 2007). The contrast with Korean threat perceptions of Japan is striking.

10. In other cases, intentions may outweigh capabilities in threat perceptions. For example, although the United States is perceived by East Asians as being the most powerful state, many states there do not fear it, and are not balancing against it, because its intentions are perceived as benign (Lind 2008b, 98). For discussion of this theoretical point, see Glaser (forthcoming 2010).

11. Berger also claims to identify an inconsistency in my argument. If "a nation's stance on history influences the extent to which a state is viewed as threatening," how can "reconciliation . . . occur without apologizing"? But there is no contradiction here. Clearly the second claim is true: many former enemies (e.g., the United States and Japan, Britain and Germany, Italy and its neighbors) have reconciled without exchanging apologies. But that in no way refutes the notion that apologetic remembrance can soothe relations. Berger and I agree that the quality of West German remembrance in the 1950s, for instance, facilitated Franco-German reconciliation.

12. Berger criticizes the strategic explanation, asserting that just as West Germany "faced enormous strategic pressures" to apologize, Japan as well "faced considerable and growing pressures to apologize." But these are two separate concepts. Strategic pressures refer to a country's threat environment and alignment, distinct from "pressures to apologize" coming from leaders of other countries or from international institutions.

\section{References}

Art, David. 2006. The Politics of the Nazi Past in Germany and Austria. New York: Cambridge University Press.

Barkan, Elazar. 2000. The Guilt of Nations: Restitution and Negotiating Social Injustices. New York: Norton.

Brooks, Stephen G. 1997. "Dueling Realisms." International Organization 51, 3: 445-477.

Cha, Victor D. 1999. Alignment Despite Antagonism: The US-Korea-Japan Security Triangle. Stanford: Stanford University Press.

Dwyer, Susan. 1999. "Reconciliation for Realists." Ethics and International Affairs 13: 81-98.

Edelstein, David M. 2002. "Managing Uncertainty: Beliefs About Intentions and the Rise of Great Powers." Security Studies 12, 2: 1-40.

Falkowski, Mateuz, and Agnieszka Popko. 2007. The Germans About Poland and the Poles 2000-2006. Warsaw: Institute for Public Affairs. Available at www.isp.org.pl/?v=page\&id=285\&ln=eng (accessed July 19, 2007). 
Gibney, Mark, Rhoda E. Howard-Hassman, Jean-Marc Coicaud, and Niklaus Steiner, eds. 2008. The Age of Apology: Facing Up to the Past. Philadelphia: University of Pennsylvania Press.

Glaser, Charles L. 1994-1995. "Realists as Optimists: Cooperation as SelfHelp.” International Security 19, 3: 50-90.

- Forthcoming 2010. Theory of Rational International Politics. Princeton: Princeton University Press.

Haas, Mark. 2005. The Ideological Origins of Great Power Politics, 1789-1989. Ithaca: Cornell University Press.

He, Yinan. 2007. "Remembering and Forgetting the War: Elite Mythmaking, Mass Reaction, and Sino-Japanese Relations, 1950-2006." History and Memory 19, 2: 43-74.

- 2009. The Search for Reconciliation: Sino-Japanese and GermanPolish Relations. Cambridge: Cambridge University Press.

Hunt, Lynn. 2008. Inventing Human Rights: A History. New York: W. W. Norton.

Kansteiner, Wulf. 2006. "Losing the War, Winning the Memory Battle: The Legacy of Nazism, World War II, and the Holocaust in the Federal Republic of Germany." In The Politics of Memory in Postwar Europe, ed. Richard Ned Lebow, Wulf Kansteiner, and Claudio Fogu. Durham, NC: Duke University Press.

Keck, Margaret, and Kathryn Sikkink. 1998. Activists Beyond Borders: Advocacy Networks in International Politics. Ithaca: Cornell University Press.

Kennedy, Paul M. 1970. "The Decline of Nationalistic History in the West, 1900-1970." Journal of Contemporary History 8, 1: 77-100.

Keohane, Robert O., and Joseph S. Nye. 1977. Power and Interdependence: World Politics in Transition. Boston: Little Brown.

Knischewski, Gerd, and Ulla Spittler. 1997. "Memories of the Second World War and National Identity in Germany." In War and Memory in the Twentieth Century, ed. Martin Evans and Ken Lunn. Oxford: Berg.

Kydd, Andrew H. 1997. "Sheep in Sheep's Clothing: Why Security Seekers Do Not Fight Each Other." Security Studies 7, 1: 115-154.

- 2005. Trust and Mistrust in International Relations. Princeton: Princeton University Press.

Lauren, Paul Gordon. 2003. The Evolution of International Human Rights: Visions Seen. 2nd ed. Philadelphia: University of Pennsylvania Press.

Lind, Jennifer. 2008a. "Memory, Apology, and International Reconciliation." Asia-Pacific Journal 47, 7: 6.

- 2008b. Sorry States: Apologies in International Politics. Ithaca: Cornell University Press.

- 2009. "The Perils of Apology: What Japan Shouldn't Learn From Germany." Foreign Affairs 88, 3: 132-146.

Mearsheimer, John J. 2001. The Tragedy of Great Power Politics. New York: Norton.

Midford, Paul. 2002. "The Logic of Reassurance and Japan's Grand Strategy." Security Studies 11, 3: 1-43. 
Nobles, Melissa. 2008. The Politics of Official Apologies. New York: Cambridge University Press.

O’Neill, Barry. 1999. Honor, Symbols, and War. Ann Arbor: University of Michigan Press.

Owen, John M., IV. 2001-2002. "Transnational Liberalism and U.S. Primacy." International Security 26, 3: 117-152.

Pick, Hella. 2000. Guilty Victim: Austria from the Holocaust to Haider. London: I. B. Tauris.

Risse, Thomas, Stephen C. Ropp, and Kathryn Sikkink, eds. 1999. The Power of Human Rights: International Norms and Domestic Change. Cambridge: Cambridge University Press.

Ron, James, and Oskar N. T. Thoms. 2007. "Do Human Rights Violations Cause Internal Conflict?" Human Rights Quarterly 29, 3: 674-705.

Schultz, Kenneth A. 1998. "Domestic Opposition and Signaling in International Crises." American Political Science Review 92, 4: 829-844.

Snyder, Jack, and Leslie J. Vinjamuri. 2003. "Trials and Errors: Principal and Pragmatism in Strategies of International Justice." International Security 28, 3: 5-44.

Torpey, John, ed. 2003. Politics and the Past. Lanham, MD: Rowman \& Littlefield.

Walt, Stephen. 1987. The Origins of Alliances. Ithaca: Cornell University Press.

Waltz, Kenneth N. 1979. Theory of International Politics. Reading, MA: Addison-Wesley. 